\title{
Mutation Analysis and Single Nucleotide Polymorphism (SNP) of TP53 in Breast Cancer In East Java
}

\author{
Rizqa Radhiyah ${ }^{1}$, I Kade Karisma Gita Ardana ${ }^{2}$, Wisnubroto ${ }^{3}$, Dwi Listyorini ${ }^{1,2}$, Hendra Susanto ${ }^{1 *}$ \\ ${ }^{1}$ Department of Biology, Faculty of Mathematice and Natural Science, State University of Malang, Malang 65145, \\ Indonesia \\ ${ }^{2}$ Division of Biotechnology Laboratory of Central Mineral dan Material Maju, Faculty of Mathematice and Natural \\ Science, State University of Malang, Malang 65145, Indonesia \\ ${ }^{3}$ Department of Oncology, Dr. Saiful Anwar General Hospital of Malang, Malang, Indonesia
}

Article history:

Submission June 2020

Revised October 2020

Accepted July 2021

*Corresponding author:

E-mail: hendrabio@um.ac.id

\begin{abstract}
The Incidence of Indonesia breast cancer case in 2018 was reported at $20.7 \%$ or 160,653 in number. The factors that caused breast cancer is TP53 gene mutation and Single Nucleotide Polymorphism (SNP). This study aimed to determine the mutation and Single Nucleotide Polymorphism (SNP) of TP53 gene in breast cancer. Samples of this study were 9 people chosen based on a purposive technique. The methods include total DNA isolation, DNA quantification, PCR, and sequencing. The results of the sequencing were then analyzed using alignment and blast. The SNP is browsed by the SNP finder on NCBI both followed by protein modeling. The results of this study indicate the existence of mutation in the exon and intron regions. Substitution of Guanine $(G)$ to base Adenine (A) is occur in codon 496 which is a coding region. SNP was also obtained in exon of sample 12. The conclusion of this study is breast cancer can be caused by mutations that occur in the exon and altered the structur of protein structure, so then affect the binding affinity between p53 and its target domain. Tp53 gene mutation is not the only cause of breast cancer staging development, there are other genes that also contribute to the development of cancer stage. In addition, Single Nucleotide Polymorphism in the TP53 gene can be used as a predisposition marker of breast cancer that has potential to be inherited.
\end{abstract}

Keywords: Breast Cancer, Mutation, Single Nucleotide Polymorphism, TP53

\section{Introduction}

Breast cancer is the most frequent disease that faced by women and the most leading cause of death around the world [1, 2]. World Health Organization (WHO) in 2018 has reported that from 18.078 .957 cancer cases, $11,6 \%$ is breast cancer. In Indonesia, breast cancer was reported as the most common cancer with the number of patient reached 58.256 and the mortality reached 22.692 [3]. The number of patient breast cancer in East Java is predicted to increase every year [4]. Based on data that had been reported by the Indonesia Ministry of Health in 2016, known that in East Java Province found 18,115 breast and cervical cancer incidence or estimated $31.1 \%$ compared in number to other provinces in Java Island.
Genetic mutations and single nucleotide polymorphism can be the factors causing breast cancer to develop [5]. One of the gene mutations that contribute to cancer is the TP53 gene mutation [6]. As has been reported, the frequency of TP53 gene mutations in other countries reached above $30 \%$, such as in the USA (45\%), Japan (47\%), Kashmir (44\%), UK (34.5\%), and African-Americans (34.5\%) [7, 8, 9].

P53 is a protein that coded by TP53 gene in the nucleus and acts as a transcription factor [10]. P53 in normal cells tends to be stable and increases when DNA damage occurs [11]. P53-wild type acts as the Guardian of the Genome, so that p53 protein will increase when DNA damage occurs, 
[12]. P53 level expression that increased can activate the genes which involved in cell cycle arrest, DNA repair, and apoptosis pathways [13, 14]. However, mutations that occur in the TP53 gene can cause the p53 protein to become defective, so it affects the DNA repair process, proliferation abnormalities, and accelerates the formation of cancer [15].

Breast cancer is also caused by single nucleotide variations or Single Nucleotide Polymorphism (SNP) [16]. Genetic variations that have a high frequency of occurrence in the genome can increase the breast cancer incidence [17]. On the other hand, breast cancer is often diagnosed at late stage and due to inadequate resources, so women with breast cancer cannot receive the early appropriate treatment $[18,19]$. In contrast, developed countries is already try to prioritize to prevent, manage, educate, and improve the treatment or therapy of breast cancer patients [20]. Mutation analysis and SNP of TP53 gene in breast cancer is one of the studies that can provide supporting information about the genomic condition of breast cancer. In addition, studies on TP53 mutations in breast cancer are not widely known in Indonesia, so studies of mutations and the SNP of TP53 gene that have a contribution to cancer development are important to be carried out, and in order to provide information on early detection and potential inheritance of breast cancer risk especially in East Java.

\section{Material and Methods \\ Total DNA isolation and quantification}

All breast cancer tissue samples are obtained from female patients by the Surgical Oncology Team of Dr. Syaiful Anwar Public Hospital. Then characterized by tumor size (T), lymph node invasion $(\mathrm{N})$, and also the incidence of metastasis $(\mathrm{M})$ refers to the TNM Breast Cancer Staging System from American Joint Committee on Cancer (AJCC). Two samples showed stage IIIB while other samples showed stage IV and its shown in Table 1. Total DNA isolation was carried out using Roche Kit ${ }^{\circledR}$ and then stored in a freezer with temperatures $-20^{\circ} \mathrm{C}-0^{\circ} \mathrm{C}$. The DNA quality and quantity test was carried out using a Nanodrop Spectrophotometer $2000 \circledR$. A total of 9 isolated samples showed the scores are more than $50 \mathrm{ng} / \mu \mathrm{l}$ and ratio between1.8-2.0. All isolated DNA has good quality and quantity, so that it can proceed to the Polymerase Chain Reaction (PCR).

\section{Polymerase Chain Reaction (PCR) and electro- phoresis \\ PCR for TP53 fragment with using forward} primer 5' TAGGTTGGCTCTGACTGTAC and for the reverse primer 5'-CAGTCAAGAA GAAAACGGCAT which designed using the National Center of Biotechnology Information blast primer (ncbi.nlm.nih.gov). PCR Cocktail consisted of $1 \mu \mathrm{l}$ forward primers, $1 \mu \mathrm{l}$ reverse primers, $10 \mu \mathrm{l}$ PCR mix, $7 \mu \mathrm{l}$ SDW, $1 \mu \mathrm{l}$ sample. NTC Cocktail consists of $1 \mu \mathrm{l}$ forward primer, $1 \mu \mathrm{l}$ reverse primer, $10 \mu \mathrm{l}$ PCR mix, $8 \mu \mathrm{l}$ SDW. The samples that were prepared is amplified using Rotor Gene Q (Qiagen $\left.{ }^{\circledR}\right)$. PCR is carried out with the following steps: 1) Initial denaturation at $94^{\circ} \mathrm{C}$ for 5 minutes, 2) Denaturation at $94^{\circ} \mathrm{C}$ for $20 \mathrm{sec}-$ onds, 3) Annealing at $52^{\circ} \mathrm{C}$ for 10 seconds, 4) Extension at $72^{\circ} \mathrm{C}$ for 30 seconds, and 5) Final Extension at $72^{\circ} \mathrm{C}$ for 5 minutes. Then the ampli-con was continued to electrophoresis which was performed by using the Mupid® Electrophoresis System and $0.8 \%$ agarose gel which is consisting of $0.4 \mathrm{~g}$ agarose, $44 \mathrm{ml}$ TBE (Tris-Boric AcidEDTA) $1 \times$ at $50 \mathrm{~V}$ for 60 minutes. Then the result is visualized using the UV transluminator gel documentation system.

\section{Sequencing, aligment, 3D protein modeling, protein docking, and SNP analysis}

The amplicon was then sequenced using the Sanger Sequencing method. TP53-wildtype are downloaded from the National Center of Biotechnology Information (NCBI) in fasta (.fas) file, then imported into the BioEdit software and continued to ClustalX software. Then, the DNA sequence is aligned and then analyzeed the nucleotides. In addition, the amino acids are downloaded from Uniprot (www.uniprot.org). Protein modeling, Swissmodel (swissmodel.expasy.org) for protein docking, is using PatchDock server (bioinfo3d.cs.ac.il/PatchDock/). Furthermore, the results of docking and protein modeling are visualized using the Pymol application which can be downloaded on Pymol (www.pymol.org/edu). In addition, SNP analysis is performed using the SNP finder on the NCBI page (ncbi.nlm.nih.gov).

\section{Results and Discussions \\ Mutation of TP53 gene in 9 samples}

Sequencing and alignment results showed mutations in exon sample 12, while 3 samples showed no mutations, and 5 samples showed mutations in 


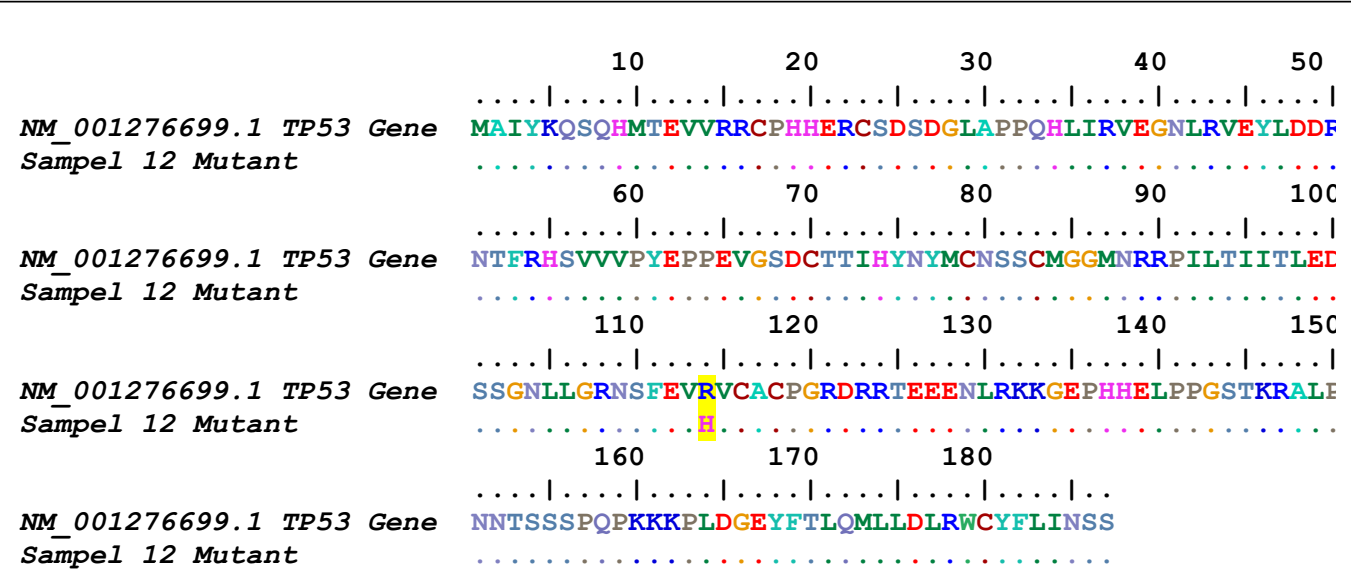

Figure 1. Amino acid alignment results showed the amino acid change (Yellow Highlight; $\mathrm{R} \rightarrow \mathrm{H}$ )
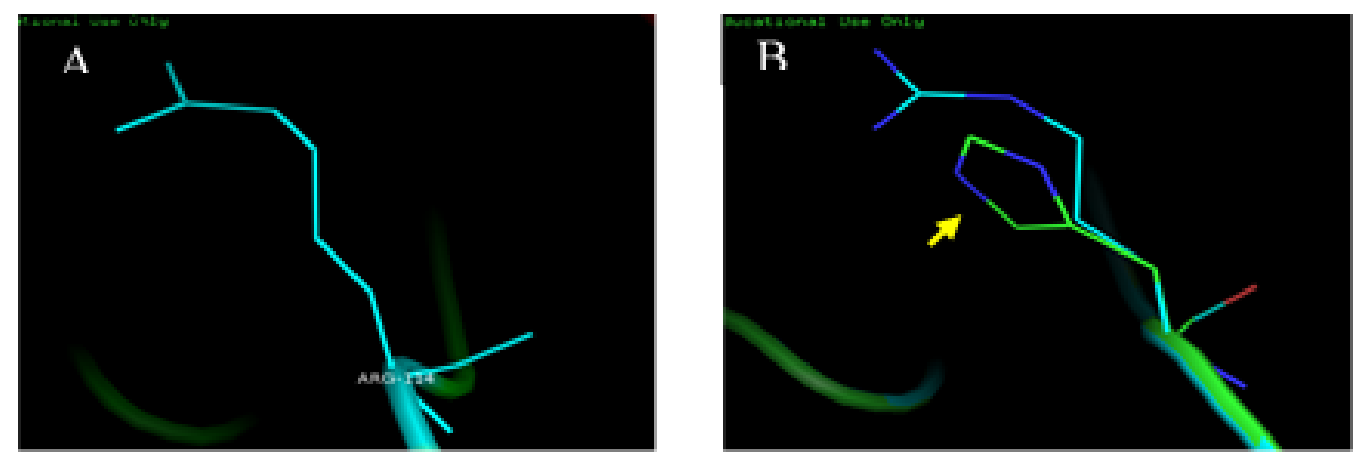

Figure 2. Visualization of p53 wild type (A) and mutant proteins (B)

introns. Colomer et al., (2003) reported that 75\% of mutations that frequently occur in the TP53 gene are substitution [21]. Substitution on the TP53 intron is the most common mutation [22]. Mutations in introns can affect regulation through splicing or interactions between proteins and its target domain [23]. Mutations that occur can cause sequences dysfunction that control the transcription [24]. In addition, the translational results of TP53 gene fragments in sample 12 are shown in Figure 1. The mutation that occurred in sample 12 is a substitution which causes an amino acid change in codon 114, Arginine to Histidine.

The visualization result of wild-type and mutant p53 are shown in Figure 2. The results showed 3D structures between p53-wild type and p53mutant which have aromatic chains (Figure 2B; yellow arrow). The change of protein structure affect the binding ability between p53 and the target domain [25]. Allteration structure of whole protein of p53 is shown in Figure 3 as the results of modeling proteins.

Petitjean et al., (2007) reported that protein structure alteration can also caused the loss of binding ability between p53 and its target domain [26]. DNA binding ability is the main activity of p53 which is involved in transcription of apoptosis and cell cycle arrest pathway $[27,28]$.

The protein structure of p53 (A) showed the normal protein structure, whereas the protein p53 (B) showed protein structure topography change and indicate the presence of aromatic chains (yellow arrows in Figure 2). These changes allow TP53 binding affinity abnormalities to occur in the target domain. This study was strengthened by the results of docking between the p53 protein and co.partner-WAF1 in the cell cycle arrest pathway [29]. The docking results show that the binding energy between mutant p53 and WAF1 is greater than the energy needed by normal p53 and WAF1. Takemura et al., (2018) reported that the amount of energy in docking results through computational methods can predict the amount of energy needed during binding proccess [30]. P53-mutant protein showed a large score of energy, which may cause the failure the binding process with its co. partner protein [31]. Sable and Jois, (2015) reported that disruption of protein - protein interaction 


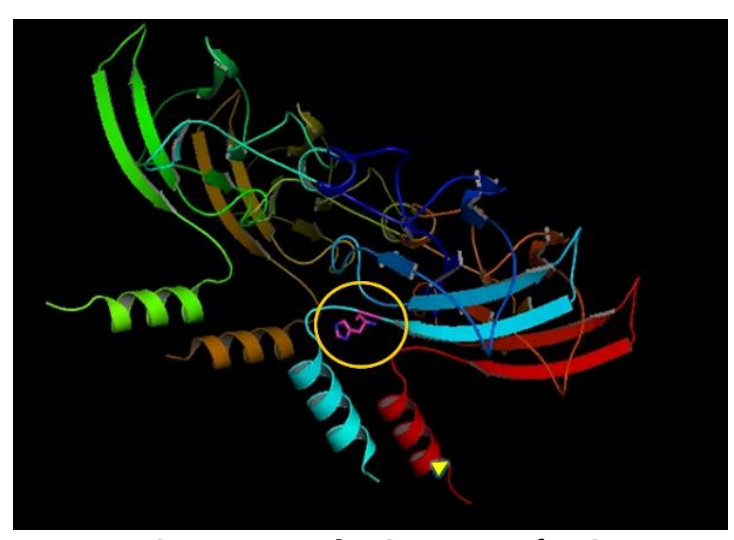

Figure 3. Topography Structure of p53-mutant

Table 1. Pathology and stadium character of samples Sample $\mathrm{T}$ N M Stage Position Metastatic \begin{tabular}{ccccccc} 
Number & & & & & & Position \\
\hline 10 & $4 \mathrm{~b}$ & 0 & 0 & IIIB & Sinis- & -
\end{tabular}

\begin{tabular}{|c|c|c|c|c|c|c|}
\hline 11 & $4 b$ & 0 & 1 & IV & Dex/Sin & $\begin{array}{c}\text { Contrala- } \\
\text { teral }\end{array}$ \\
\hline 12 & $4 c$ & 1 & 0 & IIIB & Dextral & - \\
\hline 14 & $4 a$ & $3 c$ & 1 & IV & $\begin{array}{c}\text { Sinis- } \\
\text { tral }\end{array}$ & Lung \\
\hline 15 & $4 c$ & 3 & 1 & IV & Sin/Dex & $\begin{array}{c}\text { Contrala- } \\
\text { teral }\end{array}$ \\
\hline 17 & 2 & 1 & 1 & IV & $\begin{array}{c}\text { Sinis- } \\
\text { tral }\end{array}$ & Liver \\
\hline 19 & $4 c$ & 1 & 1 & IV & Dextral & Lung \\
\hline 20 & $4 b$ & 1 & 1 & IV & Sin/Dex & $\begin{array}{c}\text { Contrala- } \\
\text { teral }\end{array}$ \\
\hline 22 & $4 \mathrm{~b}$ & 1 & 1 & IV & Dextral & Lung \\
\hline
\end{tabular}

due to increased energy needed during binding pro-ccess could trigger the development of a disease such as cancer [32]. The interaction of p53 with WAF1 plays a role in inducing CDK1 in the cell cycle arrest pathway, so that if this interaction is disrupted, the cell cycle cannot be stopped and cancer cells continue to proliferate [33].

\section{Single Nucleotide Polymorphisme in sampel 12}

Based on the results, 1 of 9 samples showed the existence of SNP, in exon sample 12 (rs28934576). Chitrala \& Yeguvapalli, (2014) reported that the dbSNPID database with rs.28934576 showed the possibility of causing damage or alter the amino acid structure which encoded in breast cancer [34]. Single Nucleotide Polymorphism is a variation of DNA base sequence due to changes in a single nucleotide [35]. SNP in the coding region (cSNPs) has a significant effect that cause protein structure change [36]. As a result, these changes affect the important acti- vities of proteins in the genome, such as TP53 which play the important role in cell cycle arrest pathway [37]. SNP occoured $>1 \%$ in a population and can be predicted [38]. In addition, the polymorphism in the TP53 gene is also related to the response to treatment in patients with breast cancer [39].

\section{Conclusion}

Based on the results of the study it can be concluded that there are mutations in the TP53 gene and Single Nucleotide Polymorphism (SNP) in exon sample 12 which causes alteration of protein structure and binding affinity. Tp53 gene mutation is not the only cause of breast cancer staging development, there are other genes that also contribute to the development of cancer stage. In addition, the SNP in the TP53 gene might be used as a marker of breast cancer predisposition which has the potential to be inherited.

\section{Acknowledgement}

The author would like to thanks to Dr. Saiful Anwar General Hospital of Malang oncology surgeon team for providing the samples and the Ministry of Education and Culture through DRPM for research funding given to the team.

\section{References}

1. Shams-White MM, Brockton NT, Mitrou P et al. (2019) Operationalizing the 2018 world cancer research fund/american institute for cancer research (WCRF/AICR) cancer prevention recommendations: A standardized scoring system. Nutrients. doi: 10.3390/nu11071572

2. Feng Y, Spezia M, Huang S et al. (2018) Breast cancer development and progression: Risk factors, cancer stem cells, signaling pathways, genomics, and molecular pathogenesis. Genes and Diseases 5 (2): 77-106. doi: 10.1016/j.gendis.2018.05.001.

3. World Health Organization (2019) Indonesia Source GLOBOCAN 2018. International Agency for Research on Cancer 256 1-2.

4. Kementrian Kesehatan RI (2015) Pusat Data dan Informasi Kesehatan Kementerian Kesehatan Republik Indonesia: Stop Kanker. Pus Data dan Inf. doi: 10.1017/CBO9781107415324.004

5. Wishart DS (2015) Is Cancer a Genetic Disease or a Metabolic Disease? EBioMedicine 2 (6): 478-479. doi: 10.1016/j.ebiom.2015.05.022.

6. Ly D, Forman D, Ferlay J et al. (2013) An international comparison of male and female breast cancer incidence rates. International Journal of Cancer 132 (8): 19181926. doi: 10.1002/ijc.27841.

7. Olivier M, Eeles R, Hollstein M et al. (2002) The IARC TP53 database: New online mutation analysis and recommendations to users. Hum Mutat. doi: 
10.1002/humu.10081

8. Eachkoti R, Hussain I, Afroze D et al. (2007) BRCA1 and TP53 mutation spectrum of breast carcinoma in an ethnic population of Kashmir, an emerging high-risk area. Cancer Lett. doi: 10.1016/j.canlet.2006.08.012

9. Hill KA, Sommer SS (2002) p53 as a mutagen test in breast cancer. Environ Mol Mutagen. doi: 10.1002/em.10065

10. O’Connor MJ (2015) Targeting the DNA Damage Response in Cancer. Molecular Cell 60 (4): 547-560. doi: 10.1016/j.molcel.2015.10.040.

11. Williams AB, Schumacher B (2016) p53 in the DNAdamage-repair process. Cold Spring Harbor Perspectives in Medicine 6 (5): 1-15. doi: 10.1101/cshperspect.a026070.

12. Davis JD (2011) DNA damage and breast cancer. World Journal of Clinical Oncology 2 (9): 329. doi: 10.5306/wjco.v2.i9.329.

13. Arizti P, Fang L, Park I et al. (2000) Tumor Suppressor p53 Is Required To Modulate BRCA1 Expression. Molecular and Cellular Biology 20 (20): 7450-7459. doi: 10.1128/mcb.20.20.7450-7459.2000.

14. Kastenhuber ER, Lowe SW (2017) Putting p53 in Context. Cell 170 (6): 1062-1078. doi: 10.1016/j.cell.2017.08.028.

15. Hientz K, Mohr A, Bhakta-Guha D, Efferth T (2017) The role of p53 in cancer drug resistance and targeted chemotherapy. Oncotarget 8 (5): 8921-8946. doi: 10.18632/oncotarget.13475.

16. Mahdi KM, Nassiri MR, Nasiri K (2013) Hereditary genes and SNPs associated with breast cancer. Asian Pacific Journal of Cancer Prevention 14 (6): 3403-3409. doi: 10.7314/APJCP.2013.14.6.3403.

17. De Bruin MA, Ford JM, Kurian AW (2012) Genetic polymorphisms as predictors of breast cancer risk. Current Breast Cancer Reports 4 (4): 232-239. doi: 10.1007/s12609-012-0091-7.

18. Shamseddine A, Tfayli A, Temraz S, Abou Mrad R (2010) Breast cancer in low- and middle-income countries: An emerging and challenging epidemic. J Oncol. doi: 10.1155/2010/490631

19. Marchetti P, Cannita K, Ricevuto E et al. (2003) Prognostic value of p53 molecular status in high-risk primary breast cancer. Annals of Oncology 14 (5): 704 708. doi: 10.1093/annonc/mdg197.

20. Shulman LN, Willett W, Sievers A, Knaul FM (2010) Breast cancer in developing countries: Opportunities for improved survival. J Oncol. doi: 10.1155/2010/595167

21. Colomer A, Erill N, Verdú M et al. (2003) Lack of p53 nuclear immunostaining is not indicative of absence of TP53 gene mutations in colorectal adenocarcinomas. Applied Immunohistochemistry and Molecular Morphology 11 (2): 130-137. doi: 10.1097/00129039200306000-00007.

22. Liu Z, Jiang Z, Gao Y et al. (2019) TP53 Mutations Promote Immunogenic Activity in Breast Cancer. J Oncol. doi: 10.1155/2019/5952836

23. Vaz-Drago R, Custódio N, Carmo-Fonseca M (2017) Deep intronic mutations and human disease. Hum Genet. doi: 10.1007/s00439-017-1809-4

24. Anczuków O, Buisson M, Léońe M et al. (2012) BRCA2 deep intronic mutation causing activation of a cryptic exon: Opening toward a new preventive therapeutic strategy. Clinical Cancer Research 18 (18): 4903-4909. doi: 10.1158/1078-0432.CCR-12-1100.

25. Ray D, Murphy KR, Gal S (2012) The DNA binding and accumulation of p53 from breast cancer cell lines and the link with serine 15 phosphorylation. Cancer Biology and Therapy 13 (10): 848-857. doi: 10.4161/cbt.20835.

26. Petitjean A, Achatz MIW, Borresen-Dale AL et al. (2007) TP53 mutations in human cancers: Functional selection and impact on cancer prognosis and outcomes. Oncogene 26 (15): 2157-2165. doi: 10.1038/sj.onc.1210302.

27. Olotu FA, Soliman MES (2019) Dynamic perspectives into the mechanisms of mutation-induced p53-DNA binding loss and inactivation using active perturbation theory: Structural and molecular insights toward the design of potent reactivators in cancer therapy. Journal of Cellular Biochemistry 120 (1): 951-966. doi: 10.1002/jcb.27458.

28. Damineni S, Rao VR, Kumar S et al. (2014) Germline mutations of TP53 gene in breast cancer. Tumor Biology 35 (9): 9219-9227. doi: 10.1007/s13277-014-2176-6.

29. Chen J (2016) The cell-cycle arrest and apoptotic and progression. Cold Spring Harbor perspectives in biology $1-16$.

30. Takemura K, Matubayasi N, Kitao A (2018) Binding free energy analysis of protein-protein docking model structures by evERdock. J Chem Phys. doi: 10.1063/1.5019864

31. Aruleba RT, Adekiya TA, Oyinloye BE, Kappo AP (2018) Structural Studies of Predicted Ligand Binding Sites and Molecular Docking Analysis of Slc2a4 as a Therapeutic Target for the Treatment of Cancer. Int J Mol Sci. doi: 10.3390/ijms19020386

32. Sable R, Jois S (2015) Surfing the protein-protein interaction surface using docking methods: Application to the design of PPI inhibitors. Molecules 20 (6): 11569 11603. doi: 10.3390/molecules200611569.

33. Engeland K (2018) Cell cycle arrest through indirect transcriptional repression by p53: I have a DREAM. Cell Death and Differentiation 25 (1): 114-132. doi: 10.1038/cdd.2017.172.

34. Chitrala KN, Yeguvapalli S (2014) Computational screening and molecular dynamic simulation of breast cancer associated deleterious non-synonymous single nucleotide polymorphisms in TP53 gene. PLoS One. doi: 10.1371/journal.pone.0104242

35. Aitken N, Smith S, Schwarz C, Morin PA (2004) Single nucleotide polymorphism (SNP) discovery in mammals: A targeted-gene approach. Molecular Ecology 13 (6): 1423-1431. doi: 10.1111/j.1365-294X.2004.02159.x.

36. Clutterbuck D, Asboe D et al. (2019) The sexual health and wellbeing of vulnerable groups in Scotland: International Journal of Environmental Research and Public Health 9 (May): 14-18. doi: 10.4103/jnsbm.JNSBM.

37. Gruel N, Lucchesi C, Raynal V et al. (2010) Lobular invasive carcinoma of the breast is a molecular entity distinct from luminal invasive ductal carcinoma. Eur $\mathrm{J}$ Cancer. doi: 10.1016/j.ejca.2010.05.013

38. Miosge LA, Field MA, Sontani Y et al. (2015) Comparison of predicted and actual consequences of missense mutations. Proceedings of the National Academy of Sciences of the United States of America 
R Radhiyah, IKKG Ardana, Wisnubroto et al., 2021 / Mutation Analysis and Single Nucleotide Polymorphism of TP53

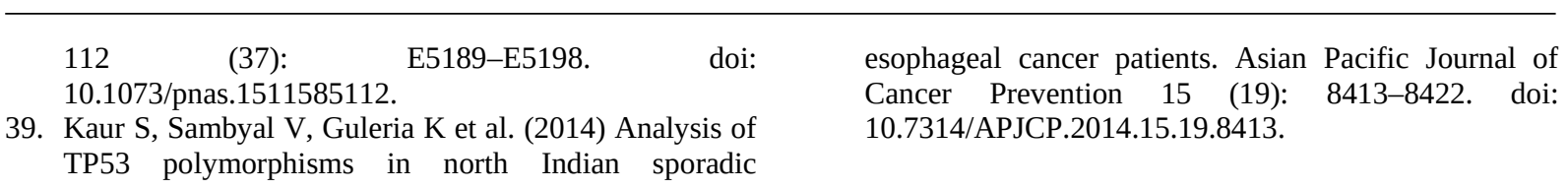

